\title{
Bids will exceed funds
}

\section{London}

IF the public statements of university vicechancellors are to be believed, then the total bids for undergraduate teaching funding submitted to the Universities Funding Council (UFC) in the next two weeks seem certain to exceed the available resources.

For the first time, student places for 1991-92 will not simply be allocated to British universities. By 22 June this year, each university must tell the UFC how many students it wishes to teach in each subject, and at what price each student can be taught (see Nature 342, 843; 1989). Except under "exceptional circumstances", these bids must not exceed 'guide prices' for each subject area, calculated by the UFC.

The idea behind the system is that universities taking on more students can make 'economies of scale', and bid at lower offer prices. By forcing the universities into competition for students, government policy to increase participation in higher education could be met at a lower cost per student.

But this is rejected by the vice-chancellors, who maintain that even the guide prices are too low. In public, vice-chancellors say they will bid for existing student numbers at the guide prices, in effect operating a cartel (although there is no formal agreement) which could defeat the UFC's purpose. Even for student places above their present numbers, most vice-chancellors say they can afford to bid only at, or just below, the guide prices.

Sir Peter Swinnerton-Dyer, chief executive of the UFC, thinks it unlikely that the vice-chancellors will maintain a unified front, because a cost-effective university able to bid for increased student numbers at competitive prices would gain under the bidding system. There are few hints at competitive bids, although Professor John Ashworth, vicechancellor of the University of Salford (shortly to move to the London School of Economics), is quick to point out that vice-chancellors' public statements on guide price bids refer only to existing student places. He says that Salford, which he describes as "one of the most cost-effective universities in the country", could take up to 40 per cent more students by the mid-1990s

But if most bids do come in at the guide price, this would need a substantial increase in the UFC's funds from government in the November public expenditure statement, as most universities are planning expansion. Few vice-chancellors expect Lord Chilver, chairman of the UFC, to fight hard for funds to match the bids. Sir Graham Hills, vice-chancellor of the University of Strathclyde, describes the present situation as "farcical", and believes that the UFC will simply impose increased student numbers on universities at some "fictional price".

This prospect angers most vicechancellors. Clark Brundin, from the University of Warwick, says that universities have prepared detailed plans for student numbers and finance up to 1994-95, to accompany their bids, and it would be irresponsible of the UFC to ignore these.

Whatever the outcome next February, when the UFC announces its decisions for student places and funding for 1991-92, most observers agree that the UFC will respond to 'overbidding' by universities by reducing the value in real terms of the guide prices in subsequent years. Swinnerton-Dyer says that the UFC has not yet decided how to link guide prices to inflation.
Faced with declining government funds per student, vice-chancellors are looking at alternative systems. With the Committee of Directors of Polytechnics, the Committee of Vice-Chancellors and Principals has set up a working party to look at funding mechanisms for higher education, which meets for the first time this week.

Professor Gerry Fowler, rector of the Polytechnic of East London and a member of the working party, believes the entire system of higher education funding is "up for grabs" over the next three years. Many university vicechancellors would like to see the cost of an expansion of higher education met in full by government. But radicals such as Hills see direct financial links between universities and government as harmful. Hills wants teaching costs switched to fees paid by students, with any government support through scholarships or vouchers, and rejects the claims of many of his colleagues that this would deter children from poorer families.

Peter Aldhous

\section{HUMAN GENE THERAPY}

\section{Approval next time round?}

\section{Washington}

THE chance of the first human gene therapy experiment winning approval improved last week when the US National Institutes of Health human gene therapy subcommittee conditionally approved an experiment to treat adenosine deaminase(ADA) deficient severe combined immunodeficiency. If its provisos are met, full approval could be given at the next meeting on 30 July.

The experiment hopes to correct the ADA deficiency by inserting a functional human ADA gene into $\mathrm{T}$ lymphocytes taken from the patient and readministering the ADA-corrected T cells back to the patient (see Nature 344, 483; 5 April 1990). The experiment was subject to tough scrutiny at the previous meeting, partly because ADA deficiency is very rare, with less than one in a million births affected, and so the pool of potential patients is very small, and partly because the risks and benefits of the experiment must be weighed against existing therapies provided by bone-marrow transplantation and enzyme replacement with the recently approved drug PEG-ADA.

As bone-marrow transplantation is the preferred method of treatment where a sibling-matched donor can be found, patients will be enrolled in the experiment only if they are considered unsuitable for bone-marrow transplantation. In addition, patients must be at least one year old and have been receiving $P E G$ ADA for a minimum of nine months so that researchers can determine the extent of immune reconstitution achieved with PEG-ADA alone.
Concerns were raised by subcommittee members at the previous meeting about the withdrawal of PEG-ADA in phase three of the planned experiment. In the hope of making the experiment more acceptable to reviewers this time round, principal researcher R. Michael Blaese of the National Cancer Institute and his associate W. French Anderson of the National Heart Lung and Blood Institute presented the subcommittee with a substantially modified experiment from which phase three had been dropped.

There had also been criticism of the lack of pre-clinical data. Countering this, Blaese and Anderson presented a brief summary of experimental studies carried out by collaborative researcher Claudio Bordignon in Milan. Bordignon has shown that ADA gene-corrected $T$ lymphocytes were able to survive and function in immunodeficient mice. Subcommittee member William N. Kelley pointed out that this is "one piece of evidence that suggests having the gene [for ADA] intracellularly is an advantage". But subcommittee members were not convinced and asked to see supporting data. It remains to be seen whether they will then be prepared to extrapolate Bordignon's research to the proposed gene therapy experiment.

Blaese says he has already met and discussed the risks of treatment with three families with ADA-deficient children. Blaese believes that "by studying three or four patients, we are going to know whether this therapy is worthwhile and whether it has a chance of working".

Diane Gershon 